\title{
Observations on the dynamics and fate of dissolved organic phosphorus in lake water and a new model of eplimnetic P cycling
}

\author{
William D. Taylor ${ }^{1}$ (1) David R. S. Lean ${ }^{2}$
}

Received: 4 May 2017 / Accepted: 11 January 2018 / Published online: 16 January 2018

(c) The Author(s) 2018. This article is an open access publication

\begin{abstract}
Phosphorus $(\mathrm{P})$ in lake water is commonly partitioned into particulate $\mathrm{P}$ and dissolved $\mathrm{P}$ by membrane filtration, and dissolved $\mathrm{P}$ is then fractionated into soluble reactive $\mathrm{P}$ (SRP, reactive with molybdate) and dissolved unreactive or organic $\mathrm{P}$ (DOP). Much of what is known about DOP is derived from radiotracer studies using gel chromatography, and summarized by a kinetic model (Lean, Science 179:678-680, 1973a; Lean, J Fish Res Board Can 30:1525-1536, 1973b). Since this work, several relevant discoveries have been made on the role of enzymes, viruses and zooplankton in regenerating dissolved $\mathrm{P}$, and the role of filtration damage in generating dissolved $\mathrm{P}$ in filtrates. Herein we present the results of new radiotracer experiments on the fate of DOP in lake water filtrates, consistent with the hypothesis that some of the high molecular weight organic $\mathrm{P}$ breaks down spontaneously to smaller molecules, which in turn break down to $\mathrm{PO}_{4}{ }^{3-}$. We use inhibitors, including competitive inhibitors of phosphatases and a commercial product (RNA-later ${ }^{\circledR}$ ) to support the hypothesis that the larger molecules include nucleic acids, and that the smaller molecules are substrates for alkaline phosphatase. We also find that colloidal $\mathrm{P}$ (i.e., P > $5000 \mathrm{MW}$ according to gel filtration) includes some virus-sized material that can be collected on 0.02 or $0.03 \mu \mathrm{m}$ filters. Finally, we provide a new model of the cycling of epilimnetic P that is consistent with these and earlier observations.
\end{abstract}

Keywords Phosphorus cycle $\cdot$ Dissolved organic phosphorus $\cdot$ Nutrient cycling $\cdot$ Colloidal phosphorus $\cdot$ Plankton

\section{Introduction}

Phosphorus $(\mathrm{P})$ in lakes is generally characterized as particulate $\mathrm{P}$ retained on membrane filters and dissolved $\mathrm{P}$ in the filtrate. Filters of several pore sizes have been used, most commonly membrane filters of $0.20-0.45 \mu \mathrm{m}$. Total dissolved P (TDP) can be further classified as soluble reactive phosphorus (SRP) and soluble unreactive phosphorus or dissolved organic phosphorus (DOP). SRP (often called dissolved reactive $\mathrm{P}$ or DRP) is that fraction of dissolved $\mathrm{P}$ that reacts directly with molybdate to form a blue complex, and includes orthophosphate $\left(\mathrm{PO}_{4}{ }^{3-}\right)$ but also some organic $\mathrm{P}$ (Baldwin 1998). TDP is measured by oxidizing filtrate

William D. Taylor

wdtaylor@uwaterloo.ca

David R. S. Lean

drslean@gmail.com

1 Department of Biology, University of Waterloo, Waterloo, ON N2L 3G1, Canada

2 Lean Environmental, P.O. Box 309, Apsley, ON K0L 1A0, Canada
$\mathrm{P}$ and measuring the resultant $\mathrm{PO}_{4}{ }^{3-}$ as for SRP. DOP is defined as the difference between TDP and SRP. Some of its components have been identified by enzyme analysis (e.g., Herbes et al. 1975) or ${ }^{31}$ P-NMR (Read et al. 2014) but the origin and fate of these is incompletely known.

Studying dynamics within the TDP is difficult by chemical methods given the low concentrations and their rapid turnover. During periods of high $\mathrm{P}$ demand ${ }^{32} \mathrm{P}-$ and ${ }^{33} \mathrm{P}-\mathrm{PO}_{4}{ }^{3-}$ are rapidly taken up by epilimnetic plankton and $\mathrm{PO}_{4}{ }^{3-}$ turnover times are rapid (Lean 1984; Lean et al. 1983, 1987). Uptake constants commonly range from 0.05 to $0.2 \mathrm{~min}^{-1}$, so after an incubation of hours dissolved ${ }^{32} \mathrm{P}$ comprises forms that have been released from the plankton. This dissolved radiolabeled $\mathrm{P}$ can be divided by gel chromatography into three components, a high molecular weight fraction excluded by the gel and termed "colloidal P", a small and lower molecular weight organic fraction ( 250 MW) not identified but called "XP", and a peak corresponding to $\mathrm{PO}_{4}{ }^{3-}$ (Lean 1973a, b). Lean's work, earlier studies by Rigler (e.g., Rigler 1966) and subsequent studies (Lean and White 1983; Fisher and Lean 1992; Hudson et al. 2000; Vandergucht et al. 2013) all demonstrate that the SRP 
concentration overestimates $\mathrm{PO}_{4}{ }^{3-}$ by several fold and hence the term SRP has been adopted for the fraction that reacts directly with molybdate.

Lean (1973a, b) developed a kinetic model of the P fractions found in lakewater (particulate $\mathrm{P}$, colloidal $\mathrm{P}, \mathrm{XP}$ and $\mathrm{PO}_{4}{ }^{3-}$ ) and identified potential pathways. These were based on several observations: (1) when ${ }^{32} \mathrm{P}-\mathrm{PO}_{4}{ }^{3-}$ is added to lake water, the XP fraction is labeled faster than the colloidal P; (2) neither fraction gets labeled unless the particulate phase is present (i.e., there is little or no direct adsorption of $\mathrm{PO}_{4}{ }^{3-}$ to organics to create XP or colloidal P); (3) the uptake of filtrate ${ }^{32} \mathrm{P}$ taken from an incubation and added back into lake water is biphasic; (4) although the colloidal fraction is commonly described as being excluded by a Sephadex G25 gel and therefore > 5000 MW, work with coarser gels and ultracentrifugation illustrates that it is actually $>5 \times 10^{6} \mathrm{MW}$; (5) when ${ }^{32} \mathrm{P}$-labelled lake water is filtered the XP fraction disappears rapidly (15-60 min), and the colloidal fraction decreases, while $\mathrm{PO}_{4}{ }^{3-}$ increases; (6) added back to lake water, filtrate $\mathrm{PO}_{4}{ }^{3-}$ is taken up rapidly, $\mathrm{XP}$ is taken up at a slower rate equivalent to the degradation rate, and colloidal $\mathrm{P}$ is taken up very slowly but with an initial "uptake" of $10-50 \%$ due to adsorption or retention by the filter; and (7) the XP fraction and at least some of the colloidal fraction is anionic.

Since this early work on the $\mathrm{P}$ cycle there have been a number of important observations relevant to DOP and its cycling among forms. For example, alkaline phosphatase activity is now known to be common in lake water, both dissolved and associated with the particulate phase, and widely used as a bioassay for P-limitation (e.g., Smith and Kalff 1981; Francko 1983; Pick 1987; Vandergucht et al. 2013; Van Moorleghem et al. 2013). It is usually measured with substrates generating fluorescent products when hydrolyzed by phosphatases at high substrate concentrations and optimal $\mathrm{pH}$, but studies using lower concentrations and ambient conditions (Taylor and Lean 1991) or radiolabelled organic $P$ compounds (Bentzen et al. 1992) demonstrate that substrates for alkaline phosphatase turn over rapidly, on the scale of minutes. We have also learned that DOP concentration varies with filtration method (Taylor 2009) and that many fragile microbes, particularly heterotrophic eukaryotes (Taylor and Lean 1981; Bloesch and Gavreili 1984; Fisher and Lean 1992) are too fragile to be separated from lake water by usual filtration methods and that their contents (including organic P) therefore contribute to DOP. On the other hand, DOP is generated naturally when cells are lyzed by viruses (Gobler et al. 1997; Middelboe and Lyck 2002) or by zooplankton grazing (Peters and Lean 1973; Taylor 1986; Titelman et al. 2008). Intracellular P can also include polyphosphate during periods of low $\mathrm{P}$ demand but under $\mathrm{P}$ limitation most is organic. We might also expect that $\mathrm{P}$ released by "sloppy" feeding and viral lysis would be largely organic, even if $\mathrm{P}$ excreted by zooplankton is mostly $\mathrm{PO}_{4}{ }^{3-}$ (e.g., Peters and Lean 1973; Taylor and Lean 1981; Taylor 1986). Viruses are now known to be abundant $\left(\sim 10^{7}-10^{8}\right.$ per $\left.\mathrm{mL}\right)$ in lakewater (Maranger and Bird 1995) and seawater (Suttle 2007), have a high $\mathrm{P}$ content and, given their size, must be part of what we measure as colloidal P.

One observation that is puzzling with respect to what we believe about DOP concerns the nature of ${ }^{32} \mathrm{P}$-labelled DOP regenerated by plankton organisms when further uptake of ${ }^{32} \mathrm{P}-\mathrm{O}_{4}{ }^{3-}$ is blocked with ${ }^{31} \mathrm{P}-\mathrm{PO}_{4}{ }^{3-}$ as a competitive inhibitor (Hudson and Taylor 1996). The regenerated ${ }^{32} \mathrm{P}$ appears to be almost entirely $\mathrm{PO}_{4}{ }^{3-}$, and there is relatively little ${ }^{32} \mathrm{P}-\mathrm{DOP}$ despite that $\mathrm{TD}^{32} \mathrm{P}$ is largely organic (Taylor 2009). In a double-label experiment on axenic algal cultures using ${ }^{33} \mathrm{P}_{-}-\mathrm{PO}_{4}{ }^{3-}$ to monitor labile compartment size and ${ }^{32} \mathrm{P}_{-} \mathrm{PO}_{4}{ }^{3-}$ to measure uptake only, exchange of $\mathrm{P}$ was shown to be the dominant pathway (Lean and Nalewajko 1976). This raises the question as to where colloidal $\mathrm{P}$ comes from, and whether it is generated by the association of small $\mathrm{P}$ molecules (i.e., XP) with other molecules as suggested by the Lean (1973a, b) model. Perhaps it is from fibrils on the surface of algae and bacteria (Leppard et al. 1977). Alternatively, if it comes from the particulate fraction by cell lysis then we hypothesize RNA is the largest component, as it is the largest pool of organic $\mathrm{P}$ in a microbial cell or in the ${ }^{32} \mathrm{P}$-labelled particulate phase of lake plankton (Cuhel and Lean 1987).

The objective of this paper is to examine the dynamics of DP fractions, as separated by gel chromatography, and to test hypotheses about the fate of those fractions as inferred by the addition of inhibitors that should interfere with those fates. In particular, we will test the hypothesis that the low molecular weight XP fraction comes from the breakdown of colloidal $\mathrm{P}$, rather than the other way around as suggested by the Lean (1973a, b) model, that some of the colloidal $\mathrm{P}$ can be collected on filters suitable for viruses, that the breakdown of XP can be blocked by competitive inhibitors of alkaline phosphatase, and that breakdown of colloidal $P$ can be inhibited competitively by RNA or by the RNA-preserving product RNA-later ${ }^{\circledR}$. We will then synthesize these new observations with the earlier ones to revise the Lean (1973a, b) model of $\mathrm{P}$ cycling in the epilimnion.

\section{Materials and method}

Experiments reported herein were performed on lake water collected on four occasions at $2 \mathrm{~m}$ depth from a site $20 \mathrm{~m}$ deep in Lake of Bays, Ontario, Canada (45.2 N, 79.0 W) during the stratified season (June-August during 2013-2015). Lake of Bays is a large, soft-water lake with total phosphorus (TP) about $5 \mu \mathrm{g} \mathrm{L} \mathrm{L}^{-1}$. Samples were brought to the Dorset Environmental Science Centre and used for experiments 
within 2 h (Fig. 1). Duplicate 600-mL aliquots (hereafter referred to as rep A and rep B) were spiked with carrier-free ${ }^{32} \mathrm{P}-\mathrm{PO}_{4}{ }^{3-}$, and the uptake of ${ }^{32} \mathrm{P}$ onto the particulate phase was followed by filtering $1-\mathrm{mL}$ aliquots $(25 \mathrm{~mm}, 0.2 \mu \mathrm{m}$ polycarbonate filters) over time, and these data were used to calculate the uptake constant for $\mathrm{PO}_{4}{ }^{3-}$ and its reciprocal, turnover time. Aliquots were collected typically at $0.5,1,2$, 3, 5, 10 and $15 \mathrm{~min}$, and at $20 \mathrm{~h}$. Depending on how rapid the kinetics were, only the first 3-5 points were used to calculate the uptake constant by curvilinear regression. After $20 \mathrm{~h}$ of incubation, $200 \mathrm{~mL}$ were removed from both replicates (see below) and the further uptake of ${ }^{32} \mathrm{P}-\mathrm{PO}_{4}{ }^{3-}$ was blocked in the remaining $400 \mathrm{~mL}$ by the addition of $1 \mathrm{mg} \mathrm{P} \mathrm{L}^{-1}$ of unlabeled $\mathrm{KH}_{2} \mathrm{PO}_{4}$. Thereafter, the increase in filtrate ${ }^{32} \mathrm{P}$ over $4-6 \mathrm{~h}$ in the $400 \mathrm{~mL}$ portions was assessed by drawing $0.5 \mathrm{~mL}$ aliquots into $1-\mathrm{mL}$ syringes through $25-\mathrm{mm}, 0.2-$ $\mu \mathrm{m}$ syringe filters at hourly intervals. The rate of increase of filtrate ${ }^{32} \mathrm{P}$ and the uptake constant were used to estimate the $\mathrm{PO}_{4}{ }^{3-}$ concentration, i.e., steady-state $\mathrm{PO}_{4}{ }^{3-}$ or $\mathrm{ssPO}_{4}{ }^{3}$ (Hudson et al. 2000). All ${ }^{32} \mathrm{P}$ samples were counted on a scintillation counter in Ecolume scintillation cocktail.

Both of the $200 \mathrm{~mL}$ aliquots of labeled water removed after $20 \mathrm{~h}$ of incubation were gently filtered through $47-\mathrm{mm}$, $0.2-\mu \mathrm{m}$ cellulose ester filters using the minimum vacuum that would produce filtrate. Importantly, $200 \mathrm{~mL}$ was added to the filter manifold but only about half of the sample was filtered while half was left above the filter. This was done by placing a $100 \mathrm{~mL}$ graduated cylinder in the filter flask, so that the drain of the filter holder was in the top of the cylinder, and filtering until just over $100 \mathrm{~mL}$ was collected. A $1-\mathrm{mL}$ aliquot of both $100 \mathrm{~mL}$ filtrates was run through the gel column (see below) to establish the initial molecular weight distribution of the dissolved $\mathrm{D}^{32} \mathrm{P}$. Then $25-\mathrm{mL}$ aliquots from each replicated $100-\mathrm{mL}$ filtrates were distributed among four beakers (i.e., a total of 8 aliquots of $25 \mathrm{~mL}$ ) and these were incubated for at least $4 \mathrm{~h}$. One pair of beakers was used as untreated controls. Another pair was spiked with glycerol phosphate and pyrophosphate (1 mg P $\mathrm{L}^{-1}$ of each) to competitively inhibit alkaline phosphatase. The other pairs, on different occasions, were spiked with RNAase, yeast RNA (as a competitive inhibitor of RNAase), or RNA-later ${ }^{\circledR}$, to alter the stability of RNA. RNA-later ${ }^{\circledR}$ is a product for the preservation of RNA in samples. An initial sample was taken when the filtrate was made, and samples of the control and treated filtrates were taken again at 1 and $4 \mathrm{~h}$, but on some occasions also at $2.5 \mathrm{~h}$.
Fig. 1 A flow chart illustrating the experiment conducted in duplicate on four occasions. Variations from this design for some dates are described in the text

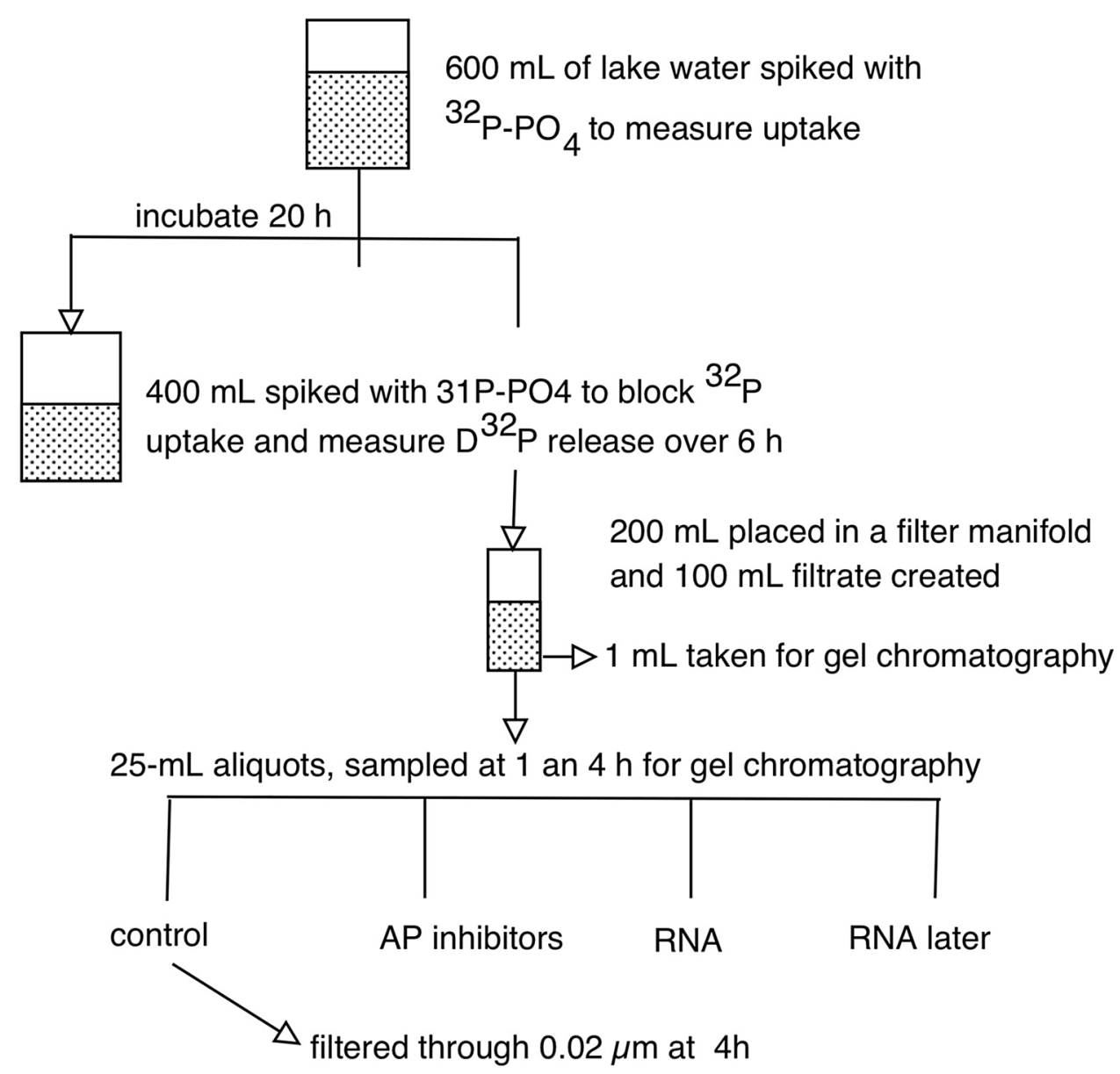


Samples (1-mL) from the eight beakers (4 treatments $\times 2$ replicates) were run through a gel column filled with Sephadex G25 fine resin, which excludes molecules $>5000 \mathrm{MW}$ and detains smaller compounds based on size. The internal diameter of the column was $25 \mathrm{~mm}$, and it was filled to a height of $25 \mathrm{~cm}$ to create a gel volume of about $125 \mathrm{~mL}$. Eluent (de-ionized water with $0.02 \% \mathrm{NaN}_{3}$ ) was run through the column at about $1 \mathrm{~mL} \mathrm{~min}^{-1}$ and 36 samples were collected to produce a chromatogram of ${ }^{32} \mathrm{P}$ molecular size from $>5000 \mathrm{MW}$ down to $\mathrm{PO}_{4}{ }^{3-}$. Based on molecular markers (see Taylor 2009) the first 12 fractions were considered colloidal P (>5000 MW), the next 12 fractions were considered smaller organic $\mathrm{P}$ molecules (including "XP") and the last 12 fractions were considered to be $\mathrm{PO}_{4}^{3}$ (although it is likely that some small organic molecules are included on the left shoulder of this peak in some runs, depending on elution rate). All samples were counted by liquid scintillation using Ecolume ${ }^{\circledR}$ scintillation cocktail and a counting time of 5 min or 10,000 counts.

On several occasions, aliquots from control beakers at $4 \mathrm{~h}$ were filtered through 0.02 or $0.03 \mu \mathrm{m}$ polycarbonate filters to assess the amount of ${ }^{32} \mathrm{P}$ in virus-sized $(0.02-0.2 \mu \mathrm{m})$ particles.

\section{Results}

$\mathrm{PO}_{4}{ }^{3-}$ turnover times measured during the experiments reported here were rapid, ranging only from 4.9 to $8.5 \mathrm{~min}$. Turnover time and regeneration rates were weakly correlated, and $\mathrm{ssPO}_{4}{ }^{-3}$ estimates ranged more widely from 0.012 to $0.19 \%$ of the total $\mathrm{P}$ (Table 1 ). The filtrates we produced from 20-h labeled lake water for further experimentation contained $1.2-2.3 \%$ of the total ${ }^{32} \mathrm{P}$.

In newly produced filtrates, the first 12 fractions obtained by gel chromatography, hereafter referred to as colloidal ${ }^{32} \mathrm{P}$ and expected to be $>5000 \mathrm{MW}$, ranged from 51 to $80 \%$ of the $\mathrm{T}^{32} \mathrm{P}$ and averaged $64 \%$ (Table 2 ). On all four experimental dates, the first replicate had a larger fraction of the $\mathrm{T}^{32} \mathrm{P}$ in the colloidal fraction than the second. The next 12 fractions, hereafter XP, ranged from 4 to $21 \%$ of the TP, and averaged $12 \%$. In contrast to the colloidal fraction, the $\mathrm{XP}$ fraction tended to increase between the first and second
Table 1 Results of ${ }^{32} \mathrm{P}-\mathrm{PO}_{4}$ uptake kinetics on epilimnetic lake water samples from Lake of Bays

\begin{tabular}{llclllll}
\hline Date & Rep & $\mathrm{K}\left(\mathrm{h}^{-1}\right)$ & $\mathrm{TT}(\mathrm{min})$ & $\mathrm{R}\left(\mathrm{d}^{-1}\right)$ & $\mathrm{ssPO} 4(\% \mathrm{TP})$ & $\mathrm{D} 32 \mathrm{P}(\% 32 \mathrm{P})$ & $\begin{array}{l}0.03-2.0 \mu \mathrm{m} \\
(\%<0.2)\end{array}$ \\
\hline 3 July 2013 & 1 & 9.5 & 6.3 & 0.26 & 0.115 & 2.34 & 23.0 \\
& 2 & 7.1 & 8.5 & 0.33 & 0.192 & 1.66 & 70.4 \\
$23 / 7 / 2013$ & 1 & 12.2 & 4.9 & 0.03 & 0.012 & 1.93 & 55.4 \\
& 2 & 13.6 & 4.4 & 0.07 & 0.022 & 1.64 & 33.6 \\
$12 / 8 / 2014$ & 1 & 11.1 & 5.4 & 0.14 & 0.051 & 1.32 & 8.5 \\
& 2 & 9.5 & 6.3 & 0.13 & 0.056 & 1.24 & 20.4 \\
$11 / 8 / 2015$ & 1 & 12.3 & 4.9 & 0.24 & 0.082 & 2.02 & 48.7 \\
& 2 & 8.3 & 7.2 & 0.13 & 0.067 & 1.73 & 63.1 \\
\hline
\end{tabular}

$\mathrm{K}$ is the uptake constant for $\mathrm{PO}_{4}$, TT is the turnover time for $\mathrm{PO}_{4}, \mathrm{R}$ is the release constant for ${ }^{32} \mathrm{P}$, ssPO4 is the steady-state estimate of $\mathrm{PO}_{4}$ concentration, $\mathrm{D}^{32} \mathrm{P}$ is the fraction of ${ }^{32} \mathrm{P}$ in $0.2-\mu \mathrm{m}$ filtrate, and $0.03-2.0$ is the fraction of dissolved $(<0.2 \mu \mathrm{m}){ }^{32} \mathrm{P}$ that can be retained on a $0.02(2013)$ or $0.03 \mu \mathrm{m}$ filter

\begin{tabular}{|c|c|c|c|c|c|c|c|c|c|c|c|c|c|c|c|c|}
\hline \multirow[t]{2}{*}{ Date } & \multirow[t]{2}{*}{ Rep } & \multicolumn{3}{|c|}{ Control, initial } & \multicolumn{3}{|c|}{ Control at $4 \mathrm{~h}$} & \multicolumn{3}{|c|}{$\begin{array}{l}\text { AP inhibitors, } \\
4 \mathrm{~h}\end{array}$} & \multicolumn{3}{|c|}{ RNA, 4 h } & \multicolumn{3}{|c|}{ RNA-later ${ }^{\circledR} 4 \mathrm{~h}$} \\
\hline & & $\mathrm{CP}$ & XP & $\mathrm{PO} 4$ & $\mathrm{CP}$ & XP & $\mathrm{PO} 4$ & $\mathrm{CP}$ & $\mathrm{XP}$ & $\mathrm{PO} 4$ & $\mathrm{CP}$ & XP & PO4 & $\mathrm{CP}$ & XP & PO4 \\
\hline \multirow[t]{2}{*}{ 3/7/13 } & A & 75 & 4 & 21 & 58 & 6 & 36 & 56 & $8^{\mathrm{a}}$ & 36 & 53 & 13 & 34 & 84 & 9 & 8 \\
\hline & B & 51 & 14 & 34 & 50 & 11 & 39 & 58 & 13 & 29 & 38 & 14 & 47 & 72 & 12 & 17 \\
\hline \multirow[t]{2}{*}{ 28/7/13 } & A & 58 & 10 & 32 & 54 & 10 & 36 & 48 & 18 & 35 & 36 & 20 & 44 & 81 & 12 & 7 \\
\hline & B & 53 & 12 & 35 & 48 & 18 & 35 & 39 & 23 & 39 & 37 & 23 & 39 & 78 & 14 & 7 \\
\hline \multirow[t]{2}{*}{$12 / 8 / 14$} & A & 80 & 7 & 13 & 78 & 10 & 12 & 60 & 22 & 18 & 64 & 18 & 17 & 91 & 7 & 2 \\
\hline & B & 76 & 12 & 12 & 61 & 20 & 19 & 61 & 22 & 17 & 54 & 21 & 25 & 93 & 6 & 1 \\
\hline \multirow[t]{2}{*}{$11 / 8 / 15$} & A & 61 & 15 & 24 & 42 & 17 & 41 & 49 & 20 & 32 & 48 & 21 & 30 & 66 & 17 & 17 \\
\hline & B & 56 & 21 & 23 & 46 & 16 & 38 & 50 & 21 & 29 & 43 & 22 & 34 & 68 & 21 & 12 \\
\hline Averages & & 64 & 12 & 24 & 55 & 14 & 32 & 53 & 20 & 29 & 47 & 19 & 34 & 79 & 12 & 9 \\
\hline
\end{tabular}

One datum was excluded from the averages, marked with superscript a
Table 2 Distribution of percent of $\mathrm{D}^{32} \mathrm{P}$ among colloidal $\mathrm{P}(\mathrm{CP}), \mathrm{XP}$ and $\mathrm{PO}_{4}{ }^{3-}$ in initial filtrates and after $4 \mathrm{~h}$ incubation for controls and three different treatments: addition of inhibitors of alkaline phosphatase (API); 2 addition of yeast RNA; and addition of RNA-later ${ }^{\circledR}$ 
Fig. 2 Changes in the relative amount of ${ }^{32} \mathrm{P}$ in: a colloidal $\mathrm{P}$; $\mathbf{b} \mathrm{XP}$. or low molecular organic $\mathrm{P}$; and $\mathbf{c} \mathrm{PO}_{4}{ }^{3-}$ during 4-h incubations of lakewater labeled for $20 \mathrm{~h}$ with ${ }^{32} \mathrm{P}-\mathrm{PO}_{4}{ }^{3-}$. The experiment was conducted on 15 August 2015

replicate. An important difference between the first and second replicates is that the first replicate of the initial $(t=0)$ filtrate was introduced immediately into the column, while the second replicate was frozen until the first column run was finished, then thawed and run immediately. All subsequent samples were also frozen until they were run. The last 12 fractions coming off the column, hereafter called $\mathrm{PO}_{4}{ }^{3-}$, ranged from 12 to $35 \%$ and averaged $26 \%$.

The colloidal ${ }^{32} \mathrm{P}$ fraction mostly declined during the 4-h incubations of control filtrate, and the ${ }^{32} \mathrm{P}_{-}-\mathrm{PO}_{4}$ fraction almost always increased (e.g., Figs. 2, 3; Table 2). The change in colloidal ${ }^{32} \mathrm{P}$ ranged from -19 to $-1 \%$ of the total ${ }^{32} \mathrm{P}$, and averaged $-11 \%$ across the four experimental dates each with two replicates (Table 2). The change in ${ }^{32} \mathrm{P}-\mathrm{PO}_{4}$ ranged from -1 to $17 \%$ of the total ${ }^{32} \mathrm{P}$, and averaged $8 \%$. The change in the intermediate-sized XP fraction was generally less, and less consistent, ranging from -5 to $8 \%$ and averaging $2 \%$.

Two treatments were devised to block the loss of colloidal ${ }^{32} \mathrm{P}$ in filtrates; addition of unlabeled RNA as a competitive inhibitor of nucleases, and addition of RNA-later ${ }^{\circledR}$. The latter produced strong results in all four cases where it was included as a treatment (e.g., Fig. 3). Rather than decreasing in filtrates, as was observed in controls, the colloidal ${ }^{32} \mathrm{P}$ fraction with RNA-later ${ }^{\circledR}$ increased to $66-93 \%$ of $\mathrm{T}^{32} \mathrm{P}$, with a mean of $79 \%$. This was an increase in that fraction of $\mathrm{T}^{32} \mathrm{P}$ relative to the freshly-prepared filtrate of from 5 to $25 \%$ (Table 2). In contrast, unlabeled yeast RNA did not preserve the colloidal fraction, as it might if it competitively inhibited labeled RNA being degraded by RNAase, but rather seemed to affect the XP fraction in a way comparable to the inhibitors of APase (see below). We also failed to affect the fate of colloidal P relative to controls by adding RNAase (data not shown).

When glycerol phosphate and pyrophosphate were added to filtrates as competitive inhibitors of phosphatases, the XP fractions were on average $6 \%$ of the $\mathrm{T}^{32} \mathrm{P}$ greater than in controls, becoming an average of $20 \%$ the $\mathrm{T}^{32} \mathrm{P}$, while the colloidal fraction was less and the $\mathrm{PO}_{4}{ }^{-3}$ changed little or not at all (Table 2; Fig. 3). This affect was observed on all occasions except for one replicate on of the first experiment. Adding yeast RNA, that we expected to block the loss of ${ }^{32} \mathrm{P}$ from colloidal fraction, had the same effect as adding glycerol phosphate and pyrophosphate, increasing the XP fraction to an average of $19 \%$ (Table 2).

Some of the $0.2-\mu \mathrm{m}$ filtrate could be retained on a $0.02-$ or $0.03-\mu \mathrm{m}$ filter. We attempted this for each experiment (Table 1) using the remains of the replicate $25-\mathrm{mL}$ control

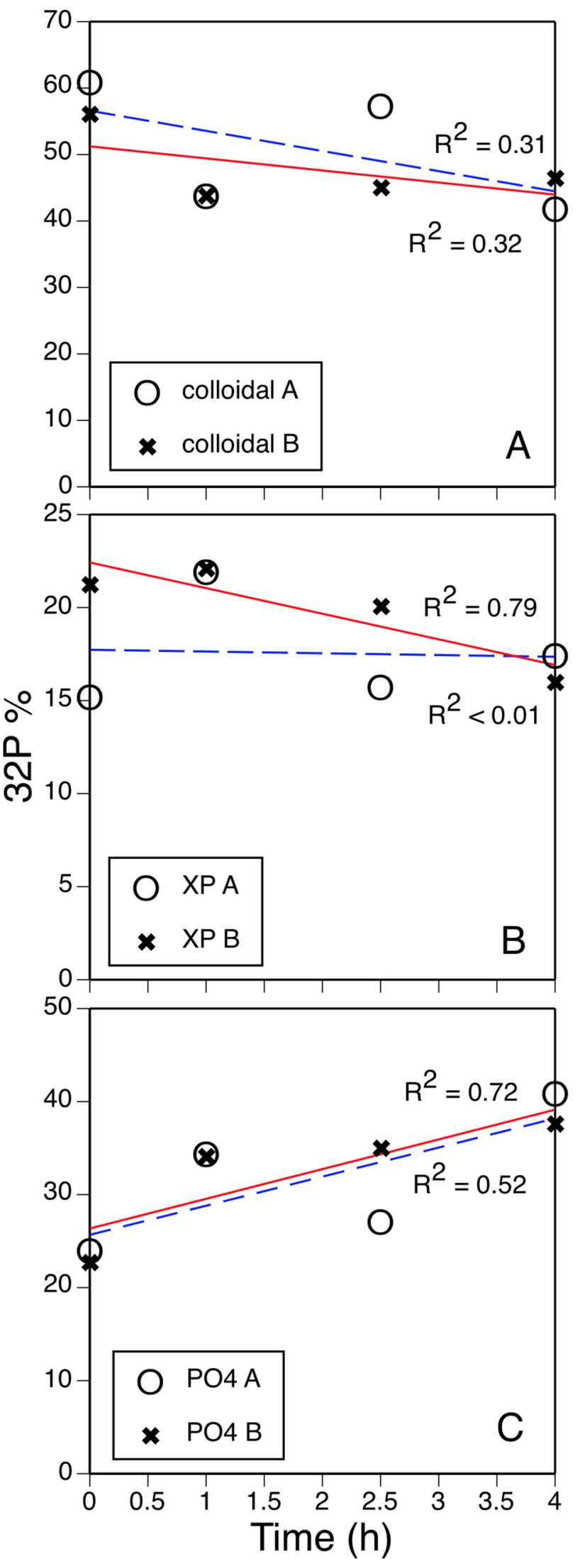


Fig. 3 The size distribution of ${ }^{32} \mathrm{P}$ in lake water just after filtration (top 2 chromatograms), after $4 \mathrm{~h}$ of incubation (next two chromatograms), after $4 \mathrm{~h}$ of incubation with competitive inhibitors of alkaline phosphatase, and after $4 \mathrm{~h}$ with RNA-later ${ }^{\circledR}$. Fractions to the left (broken bars) are ${ }^{32} \mathrm{P}$ $>5000 \mathrm{MW}$, while fractions on the on the right (hollow bars) include $\mathrm{PO}_{4}{ }^{3-}$. Between (filled bars) are molecules of intermediate size. This experiment was conducted on 23 July 2013

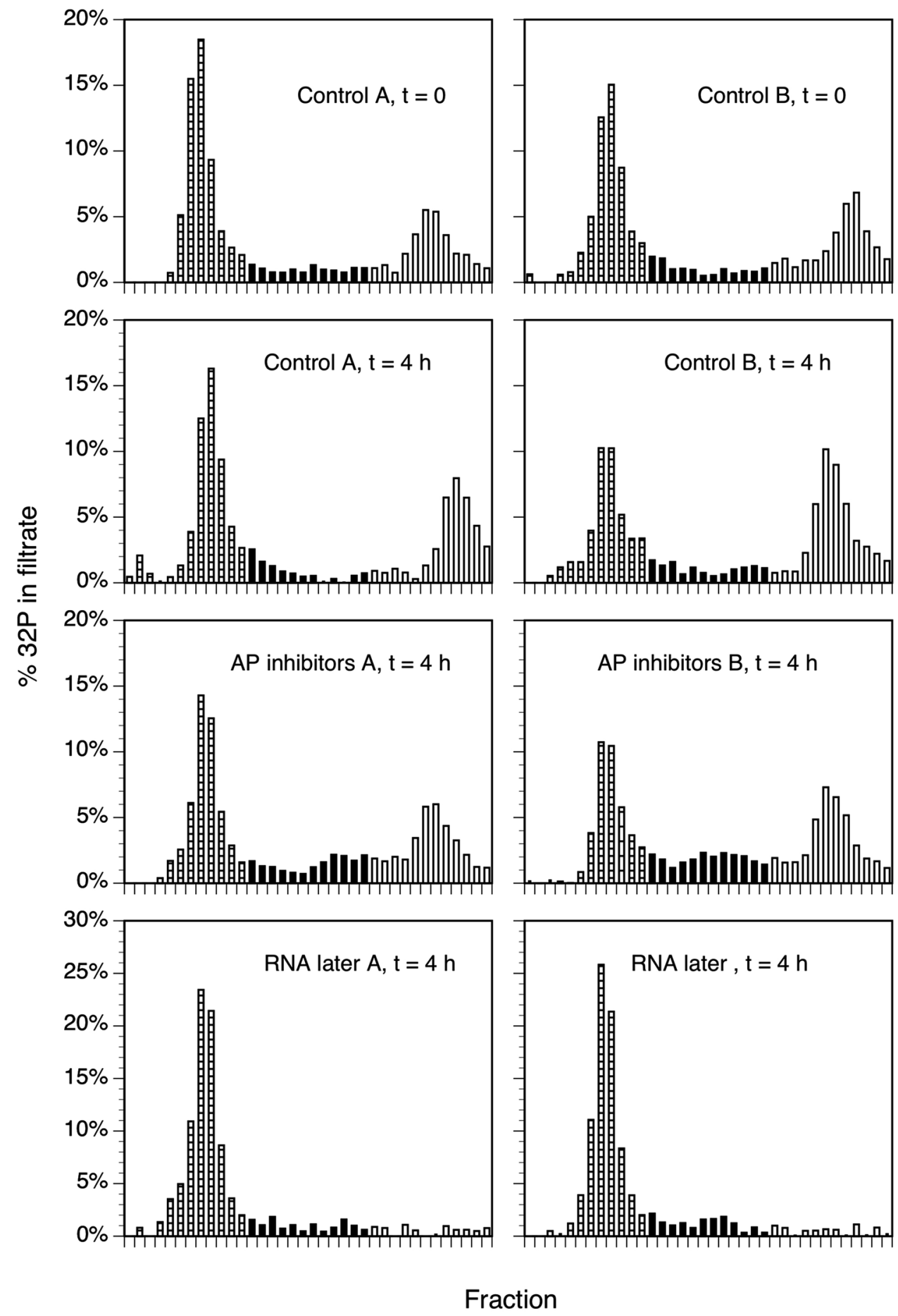

filtrates at $4 \mathrm{~h}$ of incubation time, but it was difficult to do as the $0.2-\mu \mathrm{m}$ filtrate passed through these ultrafine filters only very slowly. On the last attempt, we filtered $1-\mathrm{mL}$ aliquots of each replicate through $0.03 \mu \mathrm{m}$ filters, rinsed those filters with another $1 \mathrm{~mL}$ of filtered de-ionized water, and measured $32 \mathrm{P}$ retained. We consider this our best attempt. The ${ }^{32} \mathrm{P}$ retained was 49 and $63 \%$ of the total in 4-h control filtrates, roughly in agreement with earlier attempts to collect filtrate. Over all four attempts we found $20-70 \%$ of the $<0.2 \mu \mathrm{m} \mathrm{D}{ }^{32} \mathrm{P}$ was retained on 0.02 or $0.03-\mu \mathrm{m}$ filters. 


\section{Discussion}

These experiments performed in an oligotrophic lake confirm the earlier observation made in eutrophic lakes (Lean 1973b) that a fraction of the colloidal ${ }^{32} \mathrm{P}$ spontaneously degrades in lake water filtrate over a period of $4 \mathrm{~h}$ and that there is a corresponding increase in the ${ }^{32} \mathrm{P}_{-} \mathrm{PO}_{4}{ }^{3-}$. Furthermore, they illustrate that competitive inhibitors of phosphatases block the increase in ${ }^{32} \mathrm{P}-\mathrm{PO}_{4}{ }^{3-}$ and cause an increase in ${ }^{32} \mathrm{P}$ in intermediate fractions, strongly suggesting that the colloidal ${ }^{32} \mathrm{P}$ breaks down into monomers that are, in turn, substrates for phosphatases. These observations are consistent with possibility that the colloidal fraction of ${ }^{32} \mathrm{P}$ is at least partly nucleic acids, and therefore that intermediate fractions are short polynucleotides and nucleotides derived from them. Nucleotides are rapidly hydrolyzed in lakewater, and have turnover times measurable in minutes (Bentzen and Taylor 1991; Bentzen et al. 1992; Løvdal et al. 2007). The presence of nucleic acids in lakewater and seawater, and their lability, has been recognized by previous researchers (Paul et al. 1987; Broberg and and; Persson 1988; Matsui et al. 2001; Björkman and Karl 2005; Read et al. 2014).

We attempted to block the loss of colloidal ${ }^{32} \mathrm{P}$ using yeast RNA as a competitive inhibitor, and were unsuccessful. This could infer that this labile fraction of the colloidal 32P is not largely RNA, or that the breakdown of RNA in lakewater does not require enzymes. The experiments occurred indoors at ambient light levels, so photodegradation is unlikely. Although RNA-later ${ }^{\circledR}$ effectively preserved this labile colloidal ${ }^{32} \mathrm{P}$ fraction, this is weak evidence that the colloidal fraction is largely RNA; this product could stabilize other $\mathrm{P}$ compounds or bind $\mathrm{PO}_{4}{ }^{3}$. Nonetheless, the presence of labile RNA in filtered lake water is expected. Similar to our results, Hino (1989) found that alkaline phosphatase released $\mathrm{PO}_{4}{ }^{3-}$ more readily from lower molecular weight DOP than high molecular weight fractions, nucleases did not increase release of $\mathrm{PO}_{4}{ }^{3-}$ from DOP, and about $60 \%$ of DOP did not release $\mathrm{PO}_{4}{ }^{3-}$ in the presence of hydrolytic enzymes.

One result that we did not anticipate is that in the presence of RNA-later ${ }^{\circledR}$ we observed little or no XP or $\mathrm{PO}_{4}{ }^{3-}$ (Fig. 3). The most parsimonious explanation for this observation is that degradation of the colloidal ${ }^{32} \mathrm{P}$ fraction is prevented by this product and in the absence of some breakdown after filtration there is little or no ${ }^{32} \mathrm{P}-\mathrm{PO}_{4}$ or $\mathrm{XP}$. That we see these fractions in the other treatments at " $\mathrm{t}=0 \mathrm{~h}$ " would mean that some breakdown of colloidal

${ }^{32} \mathrm{P}$ occurs in the time it takes for the sample to be thawed and run through the column. We noticed that both the colloidal fraction and the XP fraction in filtrates that were not incubated, i.e., at " $t=0$ ", were higher in the first compared to the second replicate, the difference between these two being that the first replicate was applied immediately to the column, while the second was frozen, thawed and applied. This supports the hypothesis that $\mathrm{XP}$ and $\mathrm{PO}_{4}{ }^{3-}$ increase rapidly in filtrates.

Lean (1973a, b) described XP as a fraction of about $250 \mathrm{MW}$, i.e., very close to the $\mathrm{PO}_{4}{ }^{3-}$ peak on the chromatogram. Although 250 is lighter than nucleotides, this difference is small compared to the resolution of the gel column, so the observation of a peak in that size range supports the hypothesis that XP could be in large part nucleotides released by the breakdown of nucleic acids. Nucleotides are substrates for phosphatases (Bentzen and Taylor 1991) and nucleotidases (Ammerman and Azam 1991) in lake and sea water, and in this work we demonstrate (Table 2; Fig. 3) that other known phosphatase substrates added in excess delay the breakdown of XP, presumably by competitive inhibition.

Rather than a single peak close to the $\mathrm{PO}_{4}{ }^{3-}$ peak as described originally by Lean, in many of our chromatograms there appears to be a broad distribution of smaller organic $\mathrm{P}$ molecules between the $\mathrm{PO}_{4}{ }^{3-}$ peak and the void volume peak. This is especially true of the AP inhibitor treatment (3rd row in Fig. 3). We suggest that this reflects the existence in these chromatograms of polynucleotides generated by the internal breakage of nucleic acids. Of course, one might expect a diversity of organic $\mathrm{P}$ in lakewater, including the suite of cellular compounds that could be liberated into the water by viral lysis and zooplankton grazing. However, given that RNA and then DNA are usually the largest classes of P-containing molecules in cells, low molecular weight $\mathrm{P}$ compounds might be dominated by nucleotides unless there are species whose turnovers are much slower. Phosphonates might be candidates (Kolowith et al. 2001; Benitez-Nelson 2015; Wang et al. 2017).

A significant difference between our hypothesis that colloidal P is created within cells, and largely RNA, and the model proposed in 1973 by Lean concerns the origin and fate of colloidal P. In the 1973 model it arises from XP in the dissolved phase, but only in the presence of intact cells, and yields $\mathrm{PO}_{4}{ }^{3-}$ directly. One mechanism that would be consistent with this would be association of XP with fibrils (Leppard et al. 1977) or other extracellular colloidal material produced by cells (Fisher and Lean 1992) and the hydrolysis of that DOP by dissolved phosphatases. Sereda et al. (2009) found evidence that UV effects on DOM may affect PO4 availability in some lakes, providing indirect evidence that PO4 interacts abiotically with DOM and/or Fe. Our findings here suggest that colloidal $\mathrm{P}$ breaks down to $\mathrm{PO}_{4}{ }^{3-}$ via low molecular weight compounds, rather than directly to $\mathrm{PO}_{4}{ }^{3-}$. Since colloidal $\mathrm{P}$ is not produced except in the presence of the particulate phase, it is parsimonious to suggest that it forms within cells and is liberated by processes of cell breakdown including viral lysis, zooplankton grazing, and 


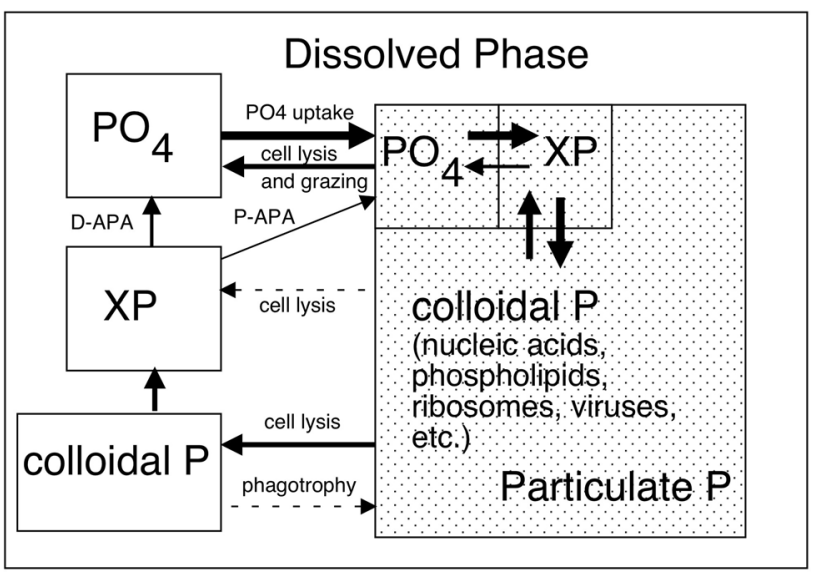

Fig. 4 A model illustrating $\mathrm{P}$ pools and fluxes consistent with earlier observations by Lean (1973a, b) and with the experiments presented here. P-APA and D-APA refer to particulate and dissolved alkaline phosphatase activity, respectively. Larger arrows indicate flows thought to be larger in magnitude, and minor flows are indicated by dashed lines

(in the lab) filtration damage. A model consistent with this view is presented in Fig. 4.

A possibly troubling observation is that two methods we can use to estimate the concentration of $\mathrm{PO}_{4}{ }^{3-}$ give different results. The filtrate $\mathrm{D}^{32} \mathrm{P}$ we created for these experiments was $1.2-2.3 \%$ of the total ${ }^{32} \mathrm{P}$, and column chromatography of fresh filtrate found that $13-35 \%$ (mean $24 \%$ ) of this was $\mathrm{PO}_{4}{ }^{3-}$ (Table 2). Therefore, we expect that $\mathrm{PO}_{4}{ }^{3-}$ should be between 0.1 and $1.3 \%$ of total ${ }^{32} \mathrm{P}$. Similarly, Taylor (2009) used dialysis to separate particulate from dissolved $\mathrm{D}^{32} \mathrm{P}(<100,000 \mathrm{MW})$ and found that DP was $0.2-0.3 \%$ of total ${ }^{32} \mathrm{P}$. However, our $\mathrm{ssPO}_{4}{ }^{3-}$ radiobioassay estimates of $\mathrm{PO}_{4}{ }^{3-}$ were only from 0.012 to $0.19 \%$ of TP, up to an order of magnitude lower. We suggest several possible reasons for this. First, the $\mathrm{ssPO}_{4}{ }^{3-}$ radiobioassay could underestimate $\mathrm{PO} 4$, because the rapid filtration required to measure the uptake constant for $\mathrm{PO}_{4}{ }^{3-}$ causes cell breakage and therefore underestimates the uptake constant. However, this error should be minor, on the order of 10\% (Taylor 2009). Second, as discussed above, it appears that labeled $\mathrm{PO}_{4}{ }^{3-}$ is created rapidly after filtration, as suggested by the consistent difference between our two replicate controls at "time 0 " and the much lower amount of $\mathrm{PO}_{4}{ }^{3-}$ when RNA-later ${ }^{\circledR}$ is added immediately to the filtrate. A third reason is that after $20 \mathrm{~h}$ of labeling, the relative ${ }^{32} \mathrm{P}$ content of slow turnover pools is still less than than their ${ }^{31} \mathrm{P}$ content. While this has been shown to be relatively unimportant for the estimation of release (Hudson and Taylor 1996) and therefore $\mathrm{ssPO}_{4}{ }^{3-}$, it may not be unimportant for the estimation of dissolved ${ }^{32} \mathrm{P}$ by filtration. Finally, it could be that some of the dissolved $\mathrm{PO}_{4}{ }^{3-}$ is created directly by the filtration step. However, even if the dissolved $\mathrm{P}$ species we studied in these experiments were augmented by filtration damage, they should be similar to those in intact lake water because natural processes such as grazing and viral lysis should create a similar suite of compounds to filtration damage, although the relative abundance of particular species may differ between these origins.

The puzzling observation we alluded to in the introduction, that $\mathrm{D}^{32} \mathrm{P}$ released by plankton is mostly $\mathrm{PO}_{4}{ }^{3-}$, whereas dissolved ${ }^{32} \mathrm{P}$ is mostly the colloidal fraction, likely reflects that colloidal $\mathrm{P}$ has a much slower turnover than $\mathrm{PO}_{4}{ }^{3-}$. Although our results indicate that some of the colloidal $\mathrm{P}$ breaks down quite rapidly, the filterable fraction that we suspect includes viruses might persist much longer. Even labile $5^{\prime}-\left(\gamma-{ }^{32} \mathrm{P}\right)$ ATP has turnover rates several times longer than those of $\mathrm{PO}_{4}{ }^{3-}$ (Bentzen and Taylor 1991).

One weakness of the model presented here is that it is largely based on limited experimental data from two lakes, one eutrophic (Lean 1973a, b) and one oligotrophic (this study) in the same part of the world, and the generality of our results remains to be demonstrated. However, the amount of DP in the epilimnion of oligotrophic and mesotrophic lakes, and at least some eutrophic lakes, is well known to be minute, and the rapid turnover of DP allows production to continue through the stratified period, a time when light and temperature are favourable. It is not unreasonable to assume, until evidence to the contrary is obtained, that the model could be broadly applicable. Another weakness of the model we present in Fig. 4 ignores the complexity of the particulate phase, presenting it as a single box, but a more complex model of P-cycling through planktonic food webs was presented by Taylor and Lean (1991) and updated by Chen and Taylor (2011), and these models could be readily integrated with this one. One advantage of these models is that from relatively simple experiments one can quickly assemble estimates of production and turnover at the base of planktonic food webs.

Acknowledgements We thank the Dorset Environmental Science Centre of the Ontario Ministry of Environment and Climate change for hosting this research and providing diverse logistic support. Mark Servos and Leslie Bragg provided access to, and assistance, with a scintillation counter when ours was down. Field and lab assistance was provided by Amy Hennessey and Vicky Jackson. Jeff Hudson provided valuable comments on an earlier draft. Brian Dixon suggested the use of RNA-later ${ }^{\circledR}$. The research was funded by a Discovery Grant from the National Science and Engineering Research Council of Canada to WDT. We have no conflict of interest.

Open Access This article is distributed under the terms of the Creative Commons Attribution 4.0 International License (http://creativecommons.org/licenses/by/4.0/), which permits unrestricted use, distribution, and reproduction in any medium, provided you give appropriate credit to the original author(s) and the source, provide a link to the Creative Commons license, and indicate if changes were made. 


\section{References}

Ammerman JW, Azam F (1991) Bacterial 5'-nucleotidase activity in coastal and estuarine marine waters: characterization of enzyme activity. Limnol Oceanogr 36:1427-1436

Baldwin DS (1998) Reactive "organic" phosphorus revisited. Water Res 32:2265-2270

Benitez-Nelson C (2015) The missing link in oceanic phosphorus cycling. Science 348:759-760

Bentzen E, Taylor WD (1991) Estimating organic P utilization by freshwater plankton using $\left[{ }^{32} \mathrm{P}\right]$ ATP. J Plankton Res 13:1223-1238

Bentzen E, Taylor WD, Millard ES (1992) The importance of dissolved organic phosphorus to phosphorus uptake by limnetic plankton. Limnol Oceanogr 37:217-231

Björkman KM, Karl DM (2005) Presence of dissolved nucleotides in the North Pacific Subtropical Gyre and their role in cycling of dissolved organic phosphorus. Aquat Microb Ecol 39:193-203

Bloesch J, Gavrieli J (1984) The influence of filtration on particulate phosphorus analysis. Verh Internat Verein Theor Angew Limnol 22:155-162

Broberg O, Persson G (1988) Particulate and dissolved phosphorus forms in freshwater: composition and analysis. Hydrobiologia 170:61-90

Chen F, Taylor WD (2011) A model of phosphorus cycling in the epilimnion of oligotrophic and mesotrophic lakes. Ecol Model 222:1103-1111

Cuhel RL, Lean DRS (1987) Subcellular phosphorus kinetics for Lake Ontario plankton. Can J Fish Aquat Sci 44:2077-2086

Fisher TR, Lean DRS (1992) Interpretation of radiophosphate dynamics in lake waters. Can J Fish Aquat Sci 49:252-258

Francko DA (1983) Size-fractionation of alkaline phosphatase activity in lake water by membrane filtration. J Freshw Ecol 2:305-309

Gobler CJ, Hutchins DA, Fisher NS, Cosper EM, Sañudo-Wilhelmy SA (1997) Release and bioavailability of C, N, P, Se, and Fe following viral lysis of a marine chrysophyte. Limnol Oceanogr 42:1492-1504

Herbes SE, Allen HE, Mancy KH (1975) Enzymatic characterization of soluble organic phosphorus in lake water. Science 187:432-434

Hino S (1989) Characterization of orthophosphate release from dissolved organic phosphorus by gel filtration and several hydrolytic enzymes. Hydrobiologia 174:40-55

Hudson JJ, Taylor WD (1996) Measuring regeneration of dissolved phosphorus in planktonic communities. Limnol Oceanogr 41:1560-1565

Hudson JJ, Taylor WD, Schindler DW (2000) Phosphate concentrations in lakes. Nature 406:54-56

Kolowith LC, Ingall ED, Benner R (2001) Composition and cycling of marine organic phosphorus. Limnol Oceanogr 46:309-320

Lean DRS (1973a) Phosphorus dynamics in lake water. Science 179:678-680

Lean DRS (1973b) Movements of phosphorus between its biologically important forms in lake water. J Fish Res Board Can 30:1525-1536

Lean DRS (1984) Metabolic indicators for phosphorus limitation. Verh Internat Verein Limnol 22:211-218

Lean DRS, Nalewajko C (1976) Phosphate exchange and organic phosphorus excretion by algae. J Fish Res Board Can 33:1312-1323

Lean DRS, White E (1983) Chemical and radiotracer measurements of P uptake by lake plankton. Can J Fish Aquat Sci 40:147-155

Lean DRS, Abbott AA, Charlton MN, Rao SS (1983) Seasonal phosphate demand for Lake Erie plankton. J Great Lakes Res 9:83-91

Lean DRS, Abbott AA, Pick FR (1987) Phosphorus deficiency of Lake Ontario plankton. Can J Fish Aquat Sci 44:2069-2076
Leppard GG, Massalski A, Lean DRS (1977) Electron opaque fibrils in lakes: their demonstration, their biological derivation and their potential significance in the redistribution of cations. Protoplasma 92:289-309

Løvdal T, Tanaka T, Thingstad TF (2007) Algal-bacterial competition for phosphorus from dissolved DNA, ATP, and orthophosphate in a mesocosm experiment. Limnol Oceanogr 52:1407-1419

Maranger R, Bird DF (1995) Viral abundance in aquatic systems: a comparison between marine and freshwaters. Mar Ecol Prog Ser 121:217-226

Matsui K, Honjo M, Kawabata Z (2001) Estimation of the fate of dissolved DNA in thermally stratified lake water from the stability of exogenous plasmid DNA. Aquat Microb Ecol 26:95-102

Middelboe M, Lyck PG (2002) Regeneration of dissolved organic matter by viral lysis in marine microbial communities. Aquat Microb Ecol 27:187-194

Paul JH, Jeffrey WH, DeFlaun MF (1987) The dynamics of extracellular DNA in the marine environment. Appl Environ Microbiol 53:170-179

Peters RH, Lean DRS (1973) The characterization of soluble phosphorus released by limnetic zooplankton. Limnol Oceanogr 18:270-279

Pick FR (1987) Interpretations of alkaline phosphatase activity in Lake Ontario. Can J Fish Aquat Sci 44:2087-2094

Read EK, Ivancic M, Hanson P, Cade-Menum BJ, McMahon KD (2014) Phosphorus speciation in a eutrophic lake by ${ }^{31} \mathrm{P}$ NMR spectroscopy. Water Res 61:229-240

Rigler FH (1966) Radiobiological analysis of inorganic phosphate in lakewater. Verh Internat Verein Theor Angew Limnol 16:465-470

Sereda JM, Hudson JJ, Taylor WD (2009) Abiotic effects of UV on planktonic P kinetics. Aquat Sci 71:127-134

Smith REH, Kalff J (1981) The effect of phosphorus limitation on algal growth rates; evidence from alkaline phosphatase. Can J Fish Aquat Sci 38:1421-1427

Suttle CA (2007) Marine viruses-major players in the global ecosystem. Nat Rev Microbiol 5:801-812

Taylor WD (1986) The effect of grazing by a ciliated protozoan on phosphorus limitation of heterotrophic bacteria in batch culture. J Protozool 33:47-52

Taylor WD (2009) Nature of dissolved P regenerated by plankton: implications for the $\mathrm{ssPO}_{4}$ radiobioassay and for the nature of dissolved P. Aquat Sci 72:12-20

Taylor WD, Lean DRS (1981) Radiotracer experiments on phosphorus uptake and release by limnetic zooplankton. Can J Fish Aquat Sci 38:1316-1321

Taylor WD, Lean DRS (1991) Phosphorus pool sizes and fluxes in the epilimnion of a mesotrophic lake. Can J Fish Aquat Sci 48:1293-1301

Titelman J, Reimann L, Holmfeldt K, Nilsen T (2008) Copepod feeding stimulates bacterioplankton activities in a low phosphorus system. Aquat Biol 2:131-141

Van Moorleghem C, De Schutter N, Smolders E, Merckx R (2013) Bioavailability of organic phosphorus to Pseudokirchneriella subcaptitata as affected by phosphorus starvation: an isotope dilution study. Water Res 47:3047-3056

Vandergucht DM, Sereda J-M, Davies JM, Hudson JJ (2013) A comparison of phosphorus deficiency indicators with steady state phosphate in lakes. Water Res 47:1816-1826

Wang Q, Dore JE, McDermott TR (2017) Methylphosphonate metabolism by Pseudomonas sp. populations contributes to the methane oversaturation paradox in an oxic freshwater lake. Environ Microbiol 19:2366-2378 